\title{
Greening small businesses in small States: the case of Barbados
}

\author{
Winston Moore and Christopher Kinch
}

\begin{abstract}
Barbados has embarked on a bold initiative to green its economy and has already made significant progress in some economic sectors (e.g. energy). This study investigates the extent to which small- and medium-sized enterprises (one of the largest segments of economic activity) on the island have adopted green initiatives and the factors that have prompted them to do so. A probit model is estimated using a firm-level database extracted from the Productivity, Technology and Innovation in the Caribbean (PROTEqIN) database maintained by Compete Caribbean. The results suggest that small and medium-sized enterprises (SMEs) have lagged behind larger firms in adopting green strategies. One of the key constraints was found to be the limited availability of technical skills and support within such enterprises. The study concludes that, if the island is to have any success in greening its SMEs, technical support will need to be made more accessible for these enterprises.
\end{abstract}

\section{Keywords}

Green economy, economic development, sustainable development, small enterprises, medium enterprises, corporate strategies, Barbados

JEL classification

Q56; C25; H25; M21

\section{Author}

Winston Moore is Deputy Principal of the Cave Hill campus de la University of the West Indies, Barbados. winston.moore@cavehill.uwi.edu.

Christopher Kinch is an economist in the Research and Economic Analysis Department of the Central Bank of Barbados. christopher.kinch@centralbank.org.bb. 


\section{Introduction}

The definition of a small enterprises varies significantly from country to country as well as from industry to industry. For example, in agriculture, "small" is defined as a business with sales of US $\$ 750,000$ or less and fewer than 500 employees, while, in retail trade, the sales and staffing thresholds are US\$38.5 million and approximately 200 employees (SBA, n/d). In Europe, a small business or microenterprise is defined as one that has 50 or fewer employees and a turnover of less than $€ 10$ million (European Commission, $\mathrm{n} / \mathrm{d})$. A small business in Barbados, in contrast, is defined as any company with paid-up capital of not more than 1 million Barbados dollars (BDS\$), sales of not more than BDS\$2,000,000 and not more than 25 employees (Barbados, 1999).

Despite its limitations in terms of size, Barbados has set itself the very bold objective of becoming the greenest economy in Latin America and the Caribbean (Moore and others, 2012). If the island is to meet its targets for greening the economy, SMEs will have to play a leading role. In most countries, SMEs are a key part of the economy, and Barbados is no exception. SMEs account for large shares of total value added, employment and tax revenues (Barrow and Greene, 1979).

The concept of a green economy shifts the debate away from a dichotomy between economic growth and environmental sustainability to a discussion of two essentially complementary and necessary conditions. This convergence of the concepts of a green economy and a sustainable development process is evident in the various working definitions of a green economy used by the United Nations Environment Programme (UNEP):

"One that results in improved human well-being and social equity, while significantly reducing environmental risks and ecological scarcities" (UNEP, n/d).

"A green economy is a system of economic activities related to the production, distribution and consumption of goods and services that results in improved human well-being over the long term, whilst not exposing future generations to significant environmental risks and ecological scarcities" (ROLAC, 2010, quoted in Moore and others, 2014, p. 48).

Most small States have narrow domestic production bases, as they tend to focus on the production of just a few goods and/or services (Commonwealth Secretariat, 1997). In addition, the types of goods that small island developing States (SIDS) export are generally not unique but are instead produced by a number of other countries around the world (Easterly and Kraay, 2000). The greening of their economies therefore represents an opportunity for these States not only to diversify their production base but also to reduce their dependence on imported inputs (e.g. fossil fuels). It is therefore not surprising that many small States have been exploring options for greening their economies (Smith, Halton and Strachan, 2014).

This study investigates the extent to which Barbadian firms have adopted green initiatives and the factors that have prompted them to decide to do so. It contributes to the literature in three main ways. First, it provides an assessment of the extent to which firms in Barbados are greening their operations. Second, using a probit model of the decision to adopt green initiatives, it also offers an assessment of the main determinants of the decision to green these businesses. Finally, it also makes a number of recommendations concerning ways to enhance support for the greening of the Barbadian economy, most of which would be relevant for other small island developing economies as well.

The remainder of this study is structured as follows. Section II provides a brief summary of the previous literature on greening small businesses. Section III then gives an assessment of the green initiatives available to small businesses in Barbados. Section IV explores the factors that motivate firms in Barbados to adopt green initiatives, while section $V$ offers some recommendations for encouraging SMEs to adopt green business practices. Section VI concludes this study with a summary of the main findings and policy recommendations. 


\section{Literature review}

The goal of greening small businesses ties in with the broader literature on the corporate social responsibility of small firms. Given the close linkages between small businesses and the community, Besser (1999) and Campbell and Park (2017) argue that small businesses should have a greater incentive to make decisions aligned with the best interests of their community. However, small business owner-managers often cite a lack of time and resources as key constraints on environmentally-friendly behaviour and community involvement, as well as saying that they see little to gain from such activities (Hitchens and others, 2005; Tilley, 1999). The remainder of this section provides a summary of the key factors that have been found to influence the environmental awareness of small businesses and/or their willingness to green their operations.

\section{Small businesses and greening}

Individually, small businesses have a very small environmental footprint. Many of them may not be subject to environmental legislation and/or may believe that, because their environmental footprint is small, they do not need to regard environmental management activities and practices as important. Gadenne, Kennedy and McKeiver (2009) examine the internal and external factors that influence firms' level of environmental awareness. Contrary to their a priori expectations, they find that many SME owner-managers are very aware of their environmental impact and the future benefits of sustainable practices for their business. Despite this high level of awareness, only a few of these businesses had actually implemented proactive environmentally sustainable practices, mainly because of the cost of adopting green practices. Brammer, Hoejmose and Marchant (2012) find that SMEs tend not to implement green practices when there are weaknesses in their business strategies, and Aragón-Correa and others (2008) find that SMEs that have unique strategic strengths (shorter lines of communication and more interaction, a founding vision, flexible external relationships and an entrepreneurial orientation) are more likely to adopt green processes. In addition, the financial performance of firms that adopt innovative environmental practices tends to be stronger. This finding suggests that while the upfront costs of greening may be prohibitive, the long-run benefit for most firms is quite significant.

Buyer requirements can also be an important determinant of whether or not small businesses adopt green initiatives. For example, small businesses that are part of a global supply chain may come under pressure from other firms to adopt greener and more sustainable business practices in order to enhance product quality, facilitate marketing and reduce costs. Lee (2008), using a database of 855 Korean SMEs and a hierarchical linear regression analysis, investigates the willingness of suppliers to participate in green supply chain initiatives. That study finds that buyers' environmental requirements are a key determinant of the decision to adopt green strategies and practices. In addition, factors such as government involvement and supplier readiness also appear to be important determinants of the decision to adopt green business practices. Tzschentke, Kirk and Lynch (2008) note the importance of consumer demands in the case of small hospitality firms as well, but they also underscore the significance of the personal, sociocultural and situational characteristics of the organization in question.

Many owner-managers of small businesses are also aware of the potential cost savings of greening their operations that can accrue from recycling, energy savings and different shipping options, among other measures. Revell, Stokes and Chen (2010) note that the results from a cross-sector survey of 220 SMEs in the United Kingdom suggest that such companies are motivated to adopt green practices, not only by regulations, but also by the prospect of reducing costs, attracting new customers, increasing staff retention and generating favourable publicity for their firms. In addition, respondent companies noted that the transition to a low-carbon economy could create business opportunities for them. On the basis of in-depth interviews 
of SMEs in the electronics industry, Lee (2009) also finds that many SME owner-managers are aware of the potential cost savings of greening their businesses. He suggests, however, that these organizations can also green their businesses by making strategic organizational changes.

\section{Regulations and green business practices}

Regulations tend to be a key driver for greening by SMEs, but they can also hinder a firm's day-to-day operations or put a halt to them altogether on account of the firm's environmental performance (Delmas and Toffel, 2004). Hoogendoorn, Guerra and van der Zwan (2015) use a database on almost 8,000 SMEs across 12 industries in 36 countries to investigate the factors that drive companies to engage in more environmentally-sound practices. They use two indicators of greening: to capture engagement in greening processes, they look at the level of investment in resource efficiency as a percentage of annual turnover and, to gauge the greenness of what a firm offers its clients or customers, they measure the percentage of annual turnover composed of green products and services. Applying an ordered logit model, they report that there appears to be an inverted $U$-shaped relationship between greening processes and firm size, with medium-sized enterprises (both in terms of employees and turnover) more likely to engage in green production and services than smaller companies. Overall, they find that the smallest enterprises in terms of turnover are less likely to be involved in any greening their product and service offerings. In addition to firm size, they find that business-to-business companies and firms that operate in industries with weak environmental regulations are also the least likely to engage in green practices. Similar results are also reported by Testa and others (2016), who note that external pressures and entrepreneurs' attitudes are the most important predictors of environmental proactivity for both small and microenterprises.

In addition to environmental regulations, incentives such as tax exemptions have also been identified as a useful policy intervention for encouraging firms to adopt green business practices. The case for "going green" seems relatively clear for small businesses but, given the technical and resource demands of greening processes, the benefits for small firms of doing so are somewhat less evident. Clemens (2006), however, finds that green economic incentives not only encourage firms to green their businesses, but also have a positive impact on the financial performance of small firms. Given the benefits of these incentives for businesses as well as for the environment, such incentives seem to be a win-win proposition for policymakers. Nevertheless, Zee, Stotsky and Ley (2002) recommend that these kinds of tax incentives should primarily be aimed at speeding up the recovery of investment costs if they are to lead to tangible results.

Regulatory and cost-saving instruments can also be powerful motivations for firms to green their businesses based on ethical, competitive or relational considerations. Gonzalez-Benito and Gonzalez-Benito (2005) assess the decisions of 184 Spanish manufacturers to pursue International Organization for Standardization (ISO) 14001 certification. Their results suggest that these companies have a high level of environmental awareness and commitment and are more likely to believe that better environmental management will give them competitive advantages. They do not, however, find any evidence that these businesses pursued environmental certification to enhance their relationships with other institutions and groups.

Doran and Ryan (2012) find that consumer demands can also heavily influence the decisions of firms to pursue green business practices. They estimate a modified innovation production function to assess the impact of regulation, consumer expectations and voluntary agreements on the likelihood of firms engaging in eco-innovation. In line with previous research, they find that regulations and customer perceptions are key drivers of a firm's decision to engage in eco-innovation. Given the positive relationship between eco-innovation and firm profitability, these findings suggest that regulators can stimulate growth by introducing green regulations and create a greener society. 


\section{Green practices and firm performance}

In more developed economies, small firms have adopted a range of environmental strategies, mainly in response to regulatory demands, and have obtained benefits from those innovations. Aragón-Correa and others (2008) examine the case of 108 SMEs in the automotive repair sector in southern Spain. The authors find that, in keeping with their a priori expectations, most SMEs tend to be reactive in adopting environmental practices. However, those firms that did take a more proactive approach outperformed their peers. Aragón-Correa and others also note that these more proactive companies usually have shorter lines of communication, a strong founder's vision, flexibility in managing external relationships and an entrepreneurial orientation.

The benefits of greening, as reflected in environmental certification, are particularly strong in some industries (for example, tourism). Segarra-Oña and others (2012) examine the comparative economic performance of Spanish hotels that have adopted environmental standards (ISO 14001). Using a database of 2,116 hotels and various measures of economic performance, they find that receiving ISO 14001 certification is usually associated with improved economic performance. However, size had a significant impact on the benefits obtained, with larger hotels reporting comparatively greater economic benefits. These results suggest that small firms may not have as much access as larger businesses have to the teams of specialists required to fully leverage the benefits of certification. Having an appropriate team of skilled persons when adopting green standards thus appears to be an important aspect of leveraging the full benefits of greening for small businesses.

Testing for the differences in motivational indicators such as corporate environmental strategies and green practices, Paulraj (2009) reports that a firm's strategy, together with environmental legislation and considerations relating to corporate environmental responsibility, have prompted companies to incorporate green business practices. These practices tend to reduce waste and the cost of inputs while minimizing a company's impact on the environment (Cordano, 1993).

\section{Green business practices in Barbados}

Much of the data used in this study are taken from the Productivity, Technology and Innovation in the Caribbean (PROTEqIN) ${ }^{1}$ database maintained by Compete Caribbean (Compete Caribbean, 2015). This database contains information on 123 Barbadian firms in both the manufacturing and services industries. Those firms were surveyed using a stratified random sampling approach, and the results are therefore based on a representative sample of the business establishments in the country.

As noted earlier, there are many programmes that promote greening in Barbados. The survey database covers two aspects of greening: environmental impact and reduced energy costs. The companies that were surveyed were asked to indicate if they had undertaken any initiatives to reduce their environmental impact or if they had adopted any strategies to reduce their energy costs. These two variables were combined to produce a single dummy variable indicator that takes a value of 1 if the company has undertaken any strategies to reduce its environmental impact or energy cost and 0 if it has not.

In general, in Barbados SMEs are less likely to pursue green initiatives than larger companies are. Table 1 disaggregates the companies in the database by number of employees and by whether or not they were pursuing green initiatives. Of the 45 companies employing 20 persons or fewer, none had pursued any initiative to green its operations. However, $45 \%$ of the other 78 companies (i.e. those

1 See [online] http://competecaribbean.org/proteqin/. 
employing 21 persons or more) were attempting to green their businesses. This is a fairly high ratio for the larger enterprises, but the relatively poor performance of the SMEs in pursuing green initiatives suggests that there is still some work to be done in order to green the corporate sector in Barbados.

Table 1

Barbados: greening and company size

\begin{tabular}{lccc}
\hline Number of employees & $\begin{array}{c}\text { Number of companies } \\
\text { pursuing green initiatives }\end{array}$ & $\begin{array}{c}\text { Total number } \\
\text { of companies }\end{array}$ & Percentage \\
\hline $0-20$ & 0 & 45 & 0 \\
\hline $21-40$ & 14 & 27 & 52 \\
\hline $41-60$ & 4 & 11 & 36 \\
\hline $61-80$ & 3 & 5 & 60 \\
\hline $81-100$ & 2 & 2 & 36 \\
\hline $101-120$ & 4 & 11 & 56 \\
\hline $121-140$ & 5 & 9 & 25 \\
\hline More than 160 & 1 & 4 & 22 \\
\hline
\end{tabular}

Source: Compete Caribbean, "Productivity, Technology, Innovation in the Caribbean”, 2016 [online database] https://publications. iadb.org/en/productivity-technology-innovation-caribbean.

On average, roughly the same percentages (approximately one third) of manufacturing and service companies were pursuing green initiatives (see figure 1).

Figure 1

Barbados: companies pursuing green initiatives, by industry (Percentages)

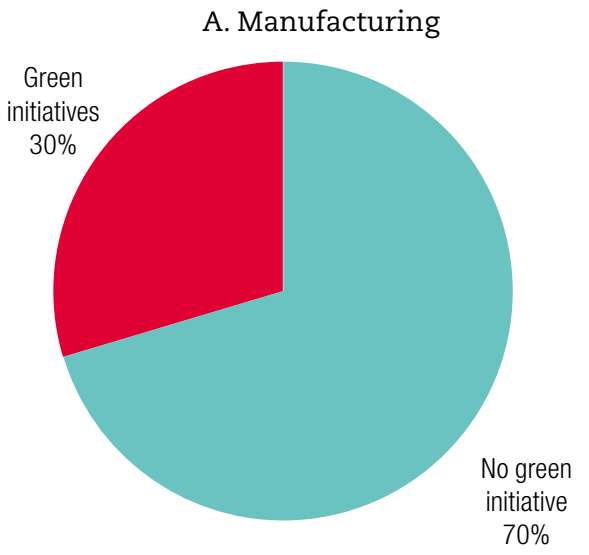

Green initiatives
B. Services

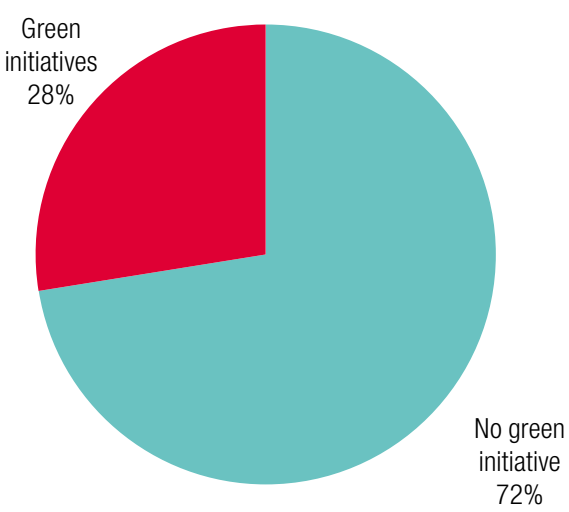

No green initiative

Source: Compete Caribbean, "Productivity, Technology, Innovation in the Caribbean”, 2016 [online database] https://publications. iadb.org/en/productivity-technology-innovation-caribbean.

Of the companies attempting to green their operations, approximately one fifth had a website and just over $10 \%$ had engaged in research and development aimed either at devising new products or at reducing costs (see figure 2). Sarkis (2003) notes that many of these companies tend to undertake environmental plans as a means of gaining a competitive advantage over rivals.

In addition to demonstrating the importance of technological variables, the results reported in figure 2 suggest that women-owned enterprises are less likely to pursue green business initiatives. This finding could be associated with many factors other than a difference in the decision-making practices of female business owners. Carter and Allen (1997), for example, argue that the characteristics of 
women-owned businesses are largely determined by their access to financial resources. This finding runs counter to the bulk of the literature on the subject, which indicates that women are willing to pay more for environmentally friendly products (Laroche, Bergeron and Barbaro-Forleo, 2001), and other studies on the issue of green purchasing (Schaper, 2002). There is some evidence of financing constraints limiting the ability of firms to pursue green initiatives, but only a small number of companies have cited the "high cost of finance" or a "lack of access to finance" as a key obstacle to the pursuit of initiatives for reducing their environmental impact.

Figure 2

Barbados: characteristics of companies adopting green initiatives

(Number of companies)

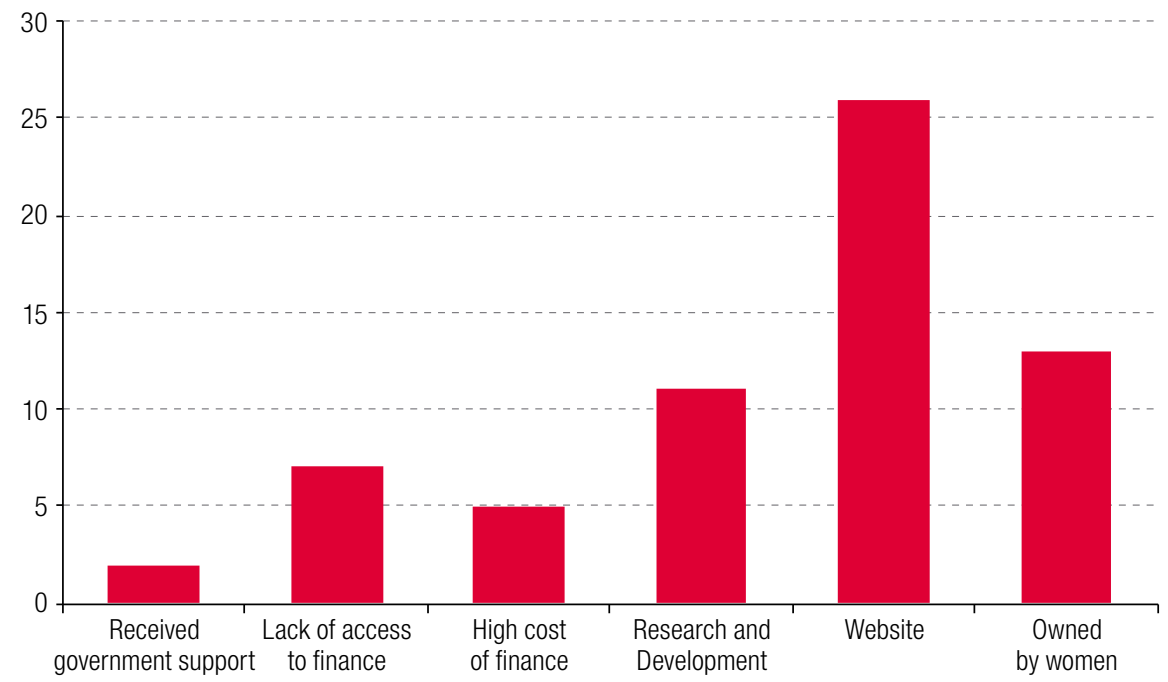

Source: Compete Caribbean, "Productivity, Technology, Innovation in the Caribbean”, 2016 [online database] https://publications. iadb.org/en/productivity-technology-innovation-caribbean.

\section{The decision to adopt green business practices}

\section{Modelling decisions to adopt green business practices}

One of the shortcomings of using descriptive statistics to draw inferences about a particular sample group is the potential effect of third variables that are not accounted for in the bivariate analysis. This issue can be addressed by estimating a probit regression of the decision to adopt green business practices. This approach is useful when the dependent variable is dichotomous, i.e. has only two values (Cameron and Trivedi, 2006), as - i n the case of our model - when we are looking at whether firms have pursued some type of green initiative or not. If we let $p_{i}$ be an indicator of whether the firm pursued some type of green initiative, then our probit model takes the form of:

$$
p_{i}=\operatorname{Pr}\left[y_{i}=1 \mid x\right]=\phi\left(x_{i}^{\prime} \beta\right)
$$

where $y_{i}=1$ when the firm pursues some type of green initiative, $\phi($.$) is the cumulative distribution$ function of a normal distribution, $\beta$ represents coefficient vectors and $x_{i}^{\prime}$ is a vector of possible explanatory variables. Assuming that the errors from the model are independent and identically distributed normal variables with a zero mean, the equation is computed using maximum likelihood estimation techniques. 
Based on the literature highlighted in section II, the explanatory variables used here include firm size (measured by the number of employees), participation in export markets, foreign ownership share, foreign customers, part of a larger supply chain, access to finance, proportion of highly skilled employees, degree of market competition and industry dummies (see table 2).

Table 2

Expected signs for explanatory variables

\begin{tabular}{lcl}
\hline Variables & Potential sign & Literature \\
\hline Firm size & - & $\begin{array}{l}\text { Aragón-Correa and others (2008); Segarra-Oña and others } \\
(2012) ; \text { Hoogendoorn, Guerra and van der Zwan (2015) }\end{array}$ \\
\hline Participation in export markets & + & Lee (2008) \\
\hline Foreign ownership share & $+/-$ & Lee (2008) \\
\hline Foreign customers & $+/-$ & Lee (2008); Tzschentke, Kirk and Lynch (2008) \\
\hline Part of a larger supply chain & + & Lee (2008); Tzschentke, Kirk and Lynch (2008) \\
\hline Access to finance & - & Aragón-Correa and others (2008) \\
\hline Proportion of highly skilled employees & + & Segarra-Oña and others (2012) \\
\hline Degree of market competition & + & Paulraj (2009) \\
\hline Industry dummies & $+/-$ & Hoogendoorn, Guerra and van der Zwan (2015) \\
\hline
\end{tabular}

Source: Prepared by the authors.

Clemens (2006) and Aragón-Correa and others (2008) argue that firm performance should improve as a result of the adoption of green initiatives because proactive environmental practices enhance the competitiveness of small firms. For example, suppliers that pursue ISO 14001 or Eco-Management and Audit Scheme (EMAS) certification tend to be more competitive internationally, regardless of size (Bellesi, Lehrer and Tal, 2005). The ISO 14001 certification demonstrates that a firm operates at the highest international standard and that it is reducing its costs by having waste management systems in place. Such firms have a marketing advantage and reduce both the risks and potential costs of litigation.

Corporate greening initiatives tend to have an effect on investors' perceptions of companies' performance in the future (Gilley and others, 2000). This is because investors react more to product-driven green initiatives than to process-driven ones. The introduction of new green products by a firm enhances its overall reputation and boosts its sales. In terms of the explanatory variable of access to financing, Haselip, Desgain and Mackenzie (2014) argue that the lack of access to credit from financial institutions such as banks has been a major barrier to the commercial viability of energy SMEs in Ghana and Senegal. This finding is in line with that of Kauffman (2005), who affirms that SMEs in Africa have very limited access to finance because of the high risk of default and a lack of financial facilities.

\section{Results}

The results of the regression analysis are reported in table 3. Column 2 provides the results from the ordinary least squares (OLS) estimation of the empirical model (also known as a linear probability model), while columns 3 and 4 show the results obtained from the probit model and the associated marginal effects of a change in each regressor on the probability that the dependent variable will take a value of 1 (pursuing green initiatives) as evaluated on the basis of the sample means. The model estimated using OLS is provided for comparison purposes only, as the OLS estimator could yield predicted probabilities greater than 1 (Cameron and Trivedi, 2006). Information on all of the variables used in the regression model was available for only 116 of the full sample of 123 firms, and the resulting number is therefore smaller than it would otherwise be. 
Table 3

Barbados: determinants of the adoption of green business practices

\begin{tabular}{|c|c|c|c|}
\hline & OLS & Probit & $\begin{array}{c}\text { Marginal effects } \\
\text { of probit regression }\end{array}$ \\
\hline Age & $\begin{array}{r}0.003 \\
(0.007)\end{array}$ & $\begin{array}{r}0.011 \\
(0.026)\end{array}$ & $\begin{array}{r}0.002 \\
(0.005) \\
\end{array}$ \\
\hline Age squared & $\begin{array}{l}-0.000 \\
(0.000)\end{array}$ & $\begin{array}{l}-0.000 \\
(0.000)\end{array}$ & $\begin{array}{l}-0.000 \\
(0.000)\end{array}$ \\
\hline Employment & $\begin{array}{r}0.002 \\
(0.002) \\
\end{array}$ & $\begin{array}{r}0.049 \\
(0.017)^{\star \star \star}\end{array}$ & $\begin{array}{r}0.009 \\
(0.002)^{\star \star \star}\end{array}$ \\
\hline Employment squared & $\begin{array}{l}-0.000 \\
(0.000)\end{array}$ & $\begin{array}{r}-0.000 \\
(0.000)^{* * \star}\end{array}$ & $\begin{array}{r}-0.000 \\
(0.000)^{\star \star \star}\end{array}$ \\
\hline Services & $\begin{array}{l}-0.040 \\
(0.114)\end{array}$ & $\begin{array}{l}-0.294 \\
(0.559)\end{array}$ & $\begin{array}{l}-0.055 \\
(0.104)\end{array}$ \\
\hline Subsidiary & $\begin{array}{l}-0.136 \\
(0.148)\end{array}$ & $\begin{array}{l}-0.399 \\
(0.500)\end{array}$ & $\begin{array}{l}-0.075 \\
(0.092)\end{array}$ \\
\hline Corporation & $\begin{array}{r}-0.204 \\
(0.106)^{*}\end{array}$ & $\begin{array}{r}-0.958 \\
(0.531)^{*}\end{array}$ & $\begin{array}{r}-0.179 \\
(0.099)^{*}\end{array}$ \\
\hline Sole proprietorship & $\begin{array}{r}-0.262 \\
(0.105)^{\star \star}\end{array}$ & $\begin{array}{r}-1.769 \\
(0.682)^{* \star \star}\end{array}$ & $\begin{array}{r}-0.331 \\
(0.124)^{\star \star \star}\end{array}$ \\
\hline Foreign-owned & $\begin{array}{l}-0.000 \\
(0.002)\end{array}$ & $\begin{array}{l}-0.003 \\
(0.006)\end{array}$ & $\begin{array}{l}-0.001 \\
(0.002)\end{array}$ \\
\hline Women-owned & $\begin{array}{r}0.140 \\
(0.089) \\
\end{array}$ & $\begin{array}{r}0.603 \\
(0.332)^{*}\end{array}$ & $\begin{array}{r}0.113 \\
(0.061) \\
\end{array}$ \\
\hline Women-managed & $\begin{array}{r}-0.165 \\
(0.089)^{*}\end{array}$ & $\begin{array}{l}-1.000 \\
(0.777)\end{array}$ & $\begin{array}{l}-0.187 \\
(0.146)\end{array}$ \\
\hline Website & $\begin{array}{r}0.093 \\
(0.095)\end{array}$ & $\begin{array}{r}0.183 \\
(0.439)\end{array}$ & $\begin{array}{r}0.034 \\
(0.082)\end{array}$ \\
\hline Customers: individuals & $\begin{array}{l}-0.339 \\
(0.185)^{*}\end{array}$ & $\begin{array}{r}-2.611 \\
(0.869)^{\star \star \star}\end{array}$ & $\begin{array}{r}-0.489 \\
(0.145)^{\star \star \star}\end{array}$ \\
\hline Customers: small businesses & $\begin{array}{l}-0.322 \\
(0.191)^{*}\end{array}$ & $\begin{array}{r}-2.203 \\
(0.802)^{\star \star \star}\end{array}$ & $\begin{array}{r}-0.413 \\
(0.137)^{\star \star \star}\end{array}$ \\
\hline Number of competitors & $\begin{array}{r}0.080 \\
(0.106)\end{array}$ & $\begin{array}{r}0.493 \\
(0.506)\end{array}$ & $\begin{array}{r}0.092 \\
(0.092)\end{array}$ \\
\hline Innovation & $\begin{array}{r}0.093 \\
(0.152)\end{array}$ & $\begin{array}{r}0.572 \\
(0.524)\end{array}$ & $\begin{array}{r}0.107 \\
(0.099)\end{array}$ \\
\hline Technical employees & $\begin{array}{r}1.825 \\
(1.146)\end{array}$ & $\begin{array}{r}16.430 \\
(6.884)^{\star \star}\end{array}$ & $\begin{array}{r}3.077 \\
(1.185)^{\star \star \star}\end{array}$ \\
\hline Access to skilled employees & $\begin{array}{l}-0.144 \\
(0.074)\end{array}$ & $\begin{array}{l}-0.469 \\
(0.356) \\
\end{array}$ & $\begin{array}{l}-0.088 \\
(0.065) \\
\end{array}$ \\
\hline Cost of finance & $\begin{array}{l}-0.072 \\
(0.122) \\
\end{array}$ & $\begin{array}{l}-0.528 \\
(0.469) \\
\end{array}$ & $\begin{array}{l}-0.099 \\
(0.088)\end{array}$ \\
\hline Access to finance & $\begin{array}{l}-0.067 \\
(0.116)\end{array}$ & $\begin{array}{l}-0.159 \\
(0.434)\end{array}$ & $\begin{array}{l}-0.030 \\
(0.081)\end{array}$ \\
\hline Government support & $\begin{array}{l}-0.114 \\
(0.170)\end{array}$ & $\begin{array}{l}-0.182 \\
(0.780) \\
\end{array}$ & $\begin{array}{l}-0.034 \\
(0.146) \\
\end{array}$ \\
\hline Awareness of programmes & $\begin{array}{l}-0.198 \\
(0.098)^{\star \star}\end{array}$ & $\begin{array}{r}-1.052 \\
(0.409)^{\star \star \star}\end{array}$ & $\begin{array}{c}-0.197 \\
(0.071)^{\star \star \star}\end{array}$ \\
\hline Technical assistance & $\begin{array}{r}0.024 \\
(0.123) \\
\end{array}$ & $\begin{array}{r}0.123 \\
(0.530) \\
\end{array}$ & $\begin{array}{r}0.023 \\
(0.099) \\
\end{array}$ \\
\hline Intercept & $\begin{array}{r}0.373 \\
(0.502)\end{array}$ & $\begin{array}{l}-1.483 \\
(2.341)\end{array}$ & - \\
\hline R-squared/pseudo R-squared & 0.329 & 0.429 & \\
\hline F-statistic(23,91) or Wald chi-square $(23)$ & $\begin{array}{r}2.990 \\
{[0.000]}\end{array}$ & $\begin{array}{l}47.280 \\
{[0.000]}\end{array}$ & \\
\hline No. of observations & 116 & 116 & \\
\hline
\end{tabular}

Source: Prepared by the authors.

Note: Standard errors are shown in parentheses and p-values in square brackets below the corresponding coefficients. Significant at $1 \%\left(^{(\star \star}\right)$, significant at $5 \%\left(^{(\star)}\right)$ and significant at $10 \%\left({ }^{\star}\right)$.

The empirical model explains about $43 \%$ more of the variation in the dependent variable than a model that only uses a constant (as indicated by the pseudo R-squared). In addition, the statistical significance of the chi-square statistic suggests that all the slopes cannot be set to zero. 
Classification tests also suggest that the model does an adequate job of classifying companies into those that do and those that do not pursue green initiatives, correctly classifying $83 \%$ of the companies in the database.

Since the model performs adequately in accounting for decisions to adopt green initiatives, it can be used to identify the most important covariates and their impact on greening decisions. The covariates that were significant at normal levels of testing included company size (proxied by employment), ownership structure, customer characteristics, composition of staff and awareness of technical assistance or programmes to support greening.

In line with the literature (Hitchens and others, 2005; Tilley, 1999), the marginal effect of the size variable suggests that larger companies are more likely to green their enterprises. To evaluate the possibility of a non-linear relationship between size and greening, the size-squared term was also included to account for the likelihood that very large firms might find it too expensive to green their operations. For both the size and the size-squared term, however, the marginal effects were quite small.

The effects of size may also be reflected in the coefficient for the ownership dummy for sole proprietorships. In the sample, sole proprietorships were 30\% less likely to engage in initiatives to green their enterprises. Many factors are usually associated with the limited decision-making space of small businesses, including liquidity constraints (Holtz-Eakin, Joulfaian and Rosen, 1994), the inaccessibility of economies of scale and differences in organizational structures (Variyam and Kraybill, 1993). One of the other difficulties that sole proprietorships may face has to do with owners' time constraints, which may reduce their ability to leverage incentives for the adoption of green initiatives and to plan effectively (Gaskill, Van Auken and Kim, 2015).

In line with the literature reviewed earlier, the types of consumer and business interactions were found to be key predictors of whether or not a firm would engage in green initiatives. On average, companies for which most of their customers were either individuals or small businesses were $40 \%$ less likely to undertake initiatives to green their businesses. This finding is in keeping with that of Lee (2008), who finds that global supply chains tend to be a more important driver of green initiatives. This also suggests that policymakers in Barbados may want to focus on educating the public about the societal benefits of purchasing goods from companies with green credentials. Such initiatives could enhance the performance of companies that have greened their businesses or products and could provide a greater incentive for other companies, once they have the necessary resources and skills, to also consider greening their businesses.

Companies with a larger proportion of employees with technical skills were significantly more likely to pursue green initiatives than their peers. Reducing a company's environmental footprint is usually accomplished by streamlining business practices and/or making technological improvements. Companies whose staff include a large proportion of employees with technical skills will find it easier not only to identify bottlenecks in the production process but also to identify and implement potential solutions (Murillo-Luna, Garcés-Ayerbe and Rivera-Torres, 2011). This kind of company was three times more likely to be pursuing green initiatives that its more low-tech peers. Given the potential benefits of greening in terms of improved firm performance, as discussed earlier, it is clear that employees with technical skills are generating a significant return on investment for the companies that employ them.

In keeping with the results of the study conducted by Gadenne, Kennedy and McKeiver (2009), our findings also indicate that many businesses are aware of the existence of facilities that can provide technical assistance for the implementation of green initiatives. Given the relatively low adoption rate of SMEs as a whole, this implies that these companies do not see the benefit of drawing on such assistance to green their enterprise. Therefore, to ensure that more businesses make use of green strategies, it may be necessary to provide more targeted forms of technical assistance. 


\section{Additional institutional mechanisms for supporting the greening of businesses}

While the magnitude of the size coefficient is relatively small, the empirical results discussed earlier suggest that the constraints posed by size are nonetheless a significant hurdle for the greening of businesses in Barbados. Overcoming this obstacle will therefore be of key importance if policymakers are to achieve their objectives for the greening of the economy, particularly in view of the important role in the domestic economy played by small businesses. Given the resource constraints encountered by the smallest businesses, it is important for these initiatives to be simple, relatively easy to implement and suited to the time constraints experienced by the owners of these enterprises.

One approach that may prove useful would be to utilize existing networks (Preisendörfer and Brüderl, 1998). Encouraging small business owners to network would help them to share knowledge and information, discuss alternative approaches to greening their businesses and possibly tap into green market opportunities. These networks already exist in Barbados thanks to the Small Business Association of Barbados, the Barbados Coalition of Service Industries and the Barbados Chamber of Commerce and Industry. Facilitating small businesses' use of these channels to network and share knowledge about greening their businesses might prove to be a low-hanging fruit that could be easily picked with the support of both the private and public sectors.

One of the most important drivers of the adoption of green strategies among Barbadian businesses is the technical skill composition of firms' employees. Companies whose personnel include a larger proportion of staff possessing technical expertise are more likely to adopt green initiatives. This finding speaks to the importance of providing training opportunities, as well as the role of educational institutions. Policymakers could achieve significant gains by supporting the expansion of training opportunities for employees in areas relating to the green economy. This kind of training would enable employees not only to support the implementation of green initiatives at their company but also to do so at the industry level as they move from job to job.

Educational institutions in Barbados may wish to consider introducing specific courses or programmes on the greening of business enterprises and exposing students in various disciplines to this concept. This would help to ensure that new employees would be sufficiently versed in green economy concepts to support further greening of the business where they are employed. It should be noted, however, that, as argued by Perron, Côté and Duffy (2006), while the importance of employee awareness of green initiatives should be acknowledged, organizations should evaluate the efficiency of their training investments to ensure that the anticipated benefits are indeed being generated.

\section{Conclusions}

The greening of the economy has become a key objective of policymakers in Barbados. To date, many of the country's green initiatives have targeted the issue of reducing the island's dependence on fossil fuels. Given the importance of small businesses in the domestic economy, however, any such initiatives need to be designed to increase the propensity of SMEs to green their businesses. To this end, this study has provided a review of current incentives for the greening of small businesses and identifies the key determinants of their propensity to adopt green business strategies.

Although small businesses face a number of difficulties in implementing green initiatives owing to their size, the Government of Barbados provides a number of tax incentives and facilitates access to funding through such mechanisms as the Energy Smart Fund. In addition, through such organizations 
as the Barbados Renewable Energy Association (BREA), firms have access to various networks for sharing information on cost-effective and efficient models for greening their day-to-day operations and/or products. In the future, the authors hope to broaden the scope of this study with a view to determining whether financial performance is positively associated with SME greening innovations in Barbados.

\section{Bibliography}

Aragón-Correa, J. and others (2008), "Environmental strategy and performance in small firms: a resource-based perspective", Journal of Environmental Management, vol. 86, No. 1, January.

Barbados (1999), "Chapter 318C", Small Business Development Act [online] https://www.investbarbados. org/legislations/small-business-development-act-cap-318c/ [accessed on: 30 May 2016].

Barrow, C. and J. Greene (1979), Small Business in Barbados: A Case of Survival, Bridgetown, Institute of Social and Economic Research - Eastern Caribbean.

Bellesi, F., D. Lehrer and A. Tal (2005), "Comparative advantage: the impact of ISO 14001 environmental certification on exports", Environmental Science \& Technology, vol. 39, No. 7.

Besser, T. (1999), "Community involvement and the perception of success among small business operators in small towns", Journal of Small Business Management, vol. 37, No. 4.

Brammer, S., S. Hoejmose and K. Marchant (2012), "Environmental management in SMEs in the UK: practices, pressures and perceived benefits", Business Strategy and the Environment, vol. 21, No. 7, November.

Cameron, A. and P. Trivedi (2005), Microeconometrics: Methods and Applications, New York, Cambridge University Press.

Campbell, J. and J. Park (2017), "Extending the resource-based view: effects of strategic orientation toward community on small business performance", Journal of Retailing and Consumer Services, vol. 34, January.

Carter, N. and K. Allen (1997), "Size determinants of women-owned businesses: choice or barriers to resources?", Entrepreneurship \& Regional Development: An International Journal, vol. 9, No. 3.

Clemens, B. (2006), "Economic incentives and small firms: does it pay to be green?", Journal of Business Research, vol. 59, No. 4, April.

Commonwealth Secretariat (1997), A Future for Small States: Overcoming Vulnerability, London.

Compete Caribbean (2016), "Productivity, Technology, Innovation in the Caribbean" [online database] https:// publications.iadb.org/en/productivity-technology-innovation-caribbean.

Cordano, M. (1993), "Making the natural connection: justifying investment in environmental innovation", Proceedings of the International Association for Business and Society, vol. 4.

Delmas, M. and M. Toffel (2004), "Stakeholders and environmental management practices: an institutional framework", Business Strategy and the Environment, vol. 13, No. 4.

Doran, J. and G. Ryan (2012), "Regulation and firm perception, eco-innovation and firm performance", European Journal of Innovation Management, vol. 15, No. 4.

Easterly, W. and A. Kraay (2000), "Small States, small problems? Income, growth, and volatility in small States", World Development, vol. 28, No. 11, November.

European Commission (n/d), "Internal market, industry, entrepreneurship and SMEs" [online] http://ec.europa. eu/growth/smes/business-friendly-environment/sme-definition/index_en.htm [accessed on: 30 May 2016].

Gadenne, D., J. Kennedy and C. McKeiver (2009), "An empirical study of environmental awareness and practices in SMEs", Journal of Business Ethics, vol. 84, No. 1, January.

Gaskill, L., H. Van Auken and H. Kim (1994), "Impact of operational planning on small business retail performance", Journal of Small Business Strategy, vol. 5, No. 1.

Gilley, K. and others (2000), "Corporate environmental initiatives and anticipated firm performance: the differential effects of process-driven versus product-driven greening initiatives", Journal of Management, vol. 26, No. 6.

González-Benito, J. and O. González-Benito (2005), "An analysis of the relationship between environmental motivations and ISO14001 certification", British Journal of Management, vol. 16, No. 2.

Haselip, J., D. Desgain and G. Mackenzie (2014), "Financing energy SMEs in Ghana and Senegal: outcomes, barriers and prospects", Energy Policy, vol. 65, January.

Hitchens, D. and others (2005), "Environmental performance, competitiveness and management of small businesses in Europe", Journal of Economic and Social Geography, vol. 96, No. 5, December. 
Holtz-Eakin, D., D. Joulfaian and H. Rosen (1994), "Entrepreneurial decisions and liquidity constraints", The RAND Journal of Economics, vol. 25, No. 2.

Hoogendoorn, B., D. Guerra and P. van der Zwan (2015), "What drives environmental practices of SMEs?", Small Business Economics, vol. 44, No. 4, April.

Kauffman, C. (2005), "Financing SMEs in Africa", OECD Development Centre Policy Insights, No. 7, Paris, Organization for Economic Cooperation and Development (OECD).

Laroche, M., J. Bergeron and G. Barbaro-Forleo (2001), "Targeting consumers who are willing to pay more for environmentally friendly products", Journal of Consumer Marketing, vol. 18, No. 6.

Lee, K. (2009), "Why and how to adopt green management into business organizations?: The case study of Korean SMEs in manufacturing industry", Management Decision, vol. 47, No. 7, July.

Lee, S. (2008), "Drivers for the participation of small and medium-sized suppliers in green supply chain initiatives", Supply Chain Management: An International Journal, vol. 13, No. 3.

Moore, W. and others (2014), Green Economy Scoping Study: Barbados, Oistins, Government of Barbados/ United Nations Environment Programme (UNEP)/University of the West Indies (UWI).

(2012), Green Economy Scoping Study Synthesis Report: Barbados, Oistins, Government of Barbados/ United Nations Environment Programme (UNEP)/University of the West Indies (UWI).

Murillo-Luna, J., C. Garcés-Ayerbe and P. Rivera-Torres (2011), "Barriers to the adoption of proactive environmental strategies", Journal of Cleaner Production, vol. 19, No. 13, September.

Paulraj, A. (2009), "Environmental motivations: a classification scheme and its impact on environmental strategies and practices", Business Strategy and the Environment, vol. 18, No. 7, November.

Perron, G., R. Côté and J. Duffy (2006), "Improving environmental awareness training in business", Journal of Cleaner Production, vol. 14, No. 6-7.

Preisendörfer, P. and J. Brüderl (1998), "Network support and the success of newly founded businesses", Small Business Economics, vol. 10, No. 3.

Revell, A., D. Stokes and H. Chen (2010), "Small businesses and the environment: turning over a new leaf", Business Strategy and the Environment, vol. 19, No. 5.

Sarkis, J. (2003), "A strategic decision framework for green supply chain management", Journal of Cleaner Production, vol. 11, No. 4, June.

SBA (Small Business Administration) (n/d), "Size standards" [online] https://www.sba.gov/contracting/ getting-started-contractor/make-sure-you-meet-sba-size-standards [accessed on: 30 May 2016].

Schaper, M. (2002), "Small firms and environmental management: predictors of green purchasing in Western Australian pharmacies", International Small Business Journal: Researching Entrepreneurship, vol. 20, No. 3, August.

Segarra-Oña, M. and others (2012), "Does environmental certification help the economic performance of hotels?: Evidence from the Spanish hotel industry", Cornell Hospitality Quarterly, vol. 53, No. 3.

Smith, N., A. Halton and J. Strachan (eds.) (2014), Transitioning to a Green Economy: Political Economy of Approaches in Small States, London, Commonwealth Secretariat.

Testa, F. and others (2016), "Factors affecting environmental management by small and micro firms: the importance of entrepreneurs' attitudes and environmental investment", Corporate Social Responsibility and Environmental Management, vol. 23, No. 6.

Tilley, F. (1999), "The gap between the environmental attitudes and the environmental behaviour of small firms", Business Strategy and the Environment, vol. 8, No. 4.

Tzschentke, N., D. Kirk and P. Lynch (2008), "Going green: decisional factors in small hospitality operations", International Journal of Hospitality Management, vol. 27, No. 1, March.

UNEP (United Nations Environment Programme) (n/d), "Green economy" [online] https://www.unenvironment. org/pt-br/node/23750\#: :text=The\%20UN\%20Environment\%20Programme\%20has,in\%20carbon\%2C\%20 resource\%20efficient\%20and.

Variyam, J. and D. Kraybill (1993), "Small firms' choice of business strategies", Southern Economic Journal, vol. 60, No. 1, July.

Zee, H., J. Stotsky and E. Ley (2002), "Tax incentives for business investment: a primer for policy makers in developing countries", World Development, vol. 30, No. 9, September. 